\title{
РОЛЬ МИКРОРНК В РАЗВИТИИ МЕТАБОЛИЧЕСКИХ НАРУШЕНИЙ У ЖЕНЩИН С ИНСУЛИНОРЕЗИСТЕНТНОСТЬЮ
}

\author{
Тофило М.А., Егорова Е.Н., Лясникова М.Б., Белякова Н.А., Цветкова И.Г. \\ ФГБОУ ВО Тверской ГМУМинздрава России, Тверь
}

АКТУАЛЬность: ключевым компонентом патогенеза абдоминального ожирения и сахарного диабета 2 типа (СД 2) является инсулинорезистентность (ИР). Однако не у всех людей с ожирением развиваются ИР и СД 2, что, возможно, связано с наличием индивидуальных молекулярно-генетических особенностей обмена веществ, в частности, с эпигенетической регуляцией экспрессии генов посредством микроРНК.

ЦЕЛЬЮ настоящего исследования было определить экспрессию двух, ассоциированных с ожирением микроРНК - miR-126 и miR-155 в плазме крови женщин, и проследить их корреляцию с показателями ИР, углеводного и жирового обменов.

МАТЕРИАЛЫ И МЕТОДЫ: венозную кровь для анализа забирали у 46 женщин с абдоминально-конституциональным ожирением и нарушением углеводного обмена (компрометированные пациентки): 10 человек - с СД 2 типа и 36 - с ИР и нарушенной толерантностью к глюкозе (НТГ). Контрольную группу составили 10 женщин без ожирения, СД и с нормальной чувствительностью к инсулину. Из биохимических показателей у обследованных изучали глюкозу натощак, липидный профиль, инсулин в сыворотке крови. Оценку ИР проводили с использованием индексов: HOMA-IR (норма $<2,55)$ и Caro-IR $(>0,33)$. МикроРHK (miR-126 и miR-155) из сыворотки крови выделяли с помощью «miRNeasy Serum/Plasma Kit» (Qiagen $\mathrm{GmbH}$, Германия) и измеряли на спектрофотометре «NanoDrop ${ }^{\mathrm{TM}}$ Lite» (Thermo Fisher Scientific,

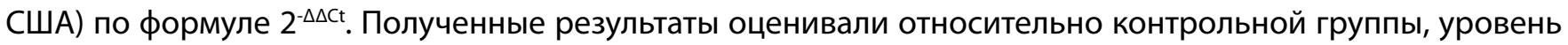
экспрессии микроРНК в которой соответствовал единице. Для оценки статистической значимости разности средних в двух группах применяли критерий Манна-Уитни. Взаимосвязь между количественными признаками оценивали путем расчета коэффициента корреляции рангов Спирмена $\left(\mathrm{r}_{\mathrm{s}}\right)$.

PЕЗУЛЬТАТЫ: проведенное исследование показало, что экспрессия miR-126 в крови у больных СД 2 составила $0,06[0,05 ; 0,07]$, что было в 16,7 раз ниже, чем в контрольной группе $(p<0,001)$, а у пациентов с ИР и без СД 2 - в 2,4 раза - 0,38 [0,27; 0,54] ( $<<0,001)$. В целом в группе метаболически компрометированных лиц уровень экспрессии miR-126 в крови был снижен относительно показателя контрольной группы в 2,9 раза ( $<<0,001)$. Экспрессия miR-155, напротив, у больных СД 2 была повышена, и составила $42,5[34,6 ; 47,2](p<0,001)$, а у пациенток с ИР и без СД $2-7,55[6,2 ; 9,1]$ (p<0,001). В целом в группе метаболически компрометированных лиц уровень экспрессии miR-155 превышал показатель контрольной группы в 8,1 раза $(\mathrm{p}<0,001)$. Анализ взаимосвязи метаболических показателей и уровней экспрессии микроРНК выявил у компрометированных пациенток наличие отрицательной корреляции miR-126 с холестерином $\left(r_{s}=-0,46 ; p<0,001\right)$ и холестеринами ЛПНП $\left(r_{s}=-0,42 ; p<0,002\right)$, ЛПОНП $\left(r_{s}=-0,50 ; p<0,001\right)$. Уровень экспрессии miR-155 у метаболически компрометированных пациенток коррелировал с глюкозой $\left(r_{s}=0,51\right.$; $\mathrm{p}<0,001)$, с НОМА-IR $\left(r_{s}=0,32 ; p<0,05\right)$, с холестерином $\left(r_{s}=0,51 ; p<0,001\right)$, холестеринами ЛПНП $\left(r_{s}=0,49\right.$; $\mathrm{p}<0,001)$, ЛПОНП ( $\left.\mathrm{r}_{\mathrm{s}}=0,51 ; \mathrm{p}<0,001\right)$ и ТГ $\left(\mathrm{r}_{\mathrm{s}}=0,50 ; \mathrm{p}<0,001\right)$.

Выводы: таким образом, результаты проведенного исследования диагностировали достоверно пониженную экспрессию miR-126 и повышенную экспрессию miR-155 в крови у женщин с абдоминальноконституциональным ожирением и инсулинорезистентностью, особенно при СД 2 типа, по сравнению с метаболически некомпрометированными пациентками. Показано, что уровни экспрессии микроРНК достоверно коррелируют с маркерами углеводного и липидного обменов. 